УДК 159.9

Устименко Тетяна Анатоліївна

кандидат психологічних наук,

Полтавський обласний інститут післядипломної педагогічної освіти імені М. В.Остроградського,

Полтава, Украӥна, t-ustymenko@rambler.ru

\title{
СТАТУС ЕТНОЦЕНТРИЗМУ В МІЖКУЛЬТУРНІЙ ВЗАЄМОДІї, ЙОГО ВИДИ ТА ФУНКЦІї
}

У статті проведено аналіз змісту установок особистості, що формуються у власній культурі та їх впливу на сприйняття зразків ін. етноспецифічних культур. Обгрунтовано понятійний апарат концепцій етнонаціональних досліджень. Наводяться результати емпіричного вивчення феномену етноцентризму, які отримані за методиками анкетного опитування щодо сприйняття різних культурних зразків та ранжування ступені їх схожості та привабливості для респондента. Застосовано концепцію культуральності, яка дозволяє побудувати модель походження та функціонування етноцентризму та пояснити причини негативізму, що ним породжується. Уперше класифіковано та описано якісні ознаки трьох принципово різних типів етноцентризму: природнього, захисного і самоцінного. Визначено, що етноцентризм $€$ частиною буття особистості, наслідком іiі соціалізації та прилучення до конкретної культури. Встановлено, що етноцентризм $є$ не лише перешкодою у міжетнічній та міжкультурній взаємодії, але виконує функцію підтримання та збереження етнічної ідентичності особистості, цілісного уявлення про внутрішній та зовнішній світ.

Ключові слова: етноцентризм, міжкультурна комунікація, глобалізація, культура, культурна особистість.

Ustymenko Tetiana, Candidate of Pedagogy Sciences, Poltava Regional Institute of Postgraduate Pedagogical Education named after M. V. Ostrogradsky, Poltava, Ukraine

\section{Ethnocentrism status in intercultural interaction, its types and functions}

The article analyzes the contents of individual units that are formed in their own culture; it also examines their impact on the perception of other specific ethnic cultures examples. The conceptual apparatus of the ethnic studies concepts is justified. The results of the empirical study of the ethnocentrism phenomenon obtained by questionnaire survey techniques of different cultural patterns perceptions and degree of their similarity ranking and appeal to the respondent are disclosed. The author 
apples the concept of culture that enables to form a the ethnocentrism origin and functioning model and explain the negativity it generates. Qualitative features of three fundamentally different types of ethnocentrism such as natural, protective and selfsufficient are classified and described for the first time. Ethnocentrism is stated to be not the only obstacle to interethnic and intercultural interaction, but the function of the maintenance and preservation of the individual ethnic identity, integrated picture of the inside and the outside world.

Key words: ethnocentrism, intercultural communication, globalization, culture, cultural identity.

Устименко Татьяна Анатольевна, кандидат психологических наук, Полтавский областной институт последипломного педагогического образования имени М. В. Остроградского, Полтава, Украина

\section{Статус этноцентризма в межкультурном взаимодействии, его виды и функции}

В статье проведен анализ содержания установок личности, что формируются в собственной культуре и их влияние на восприятий образцов вторых етноспецифических культур. Обоснованно понятийній аппарат концепций этнонациональных исследований. Приводятся результаты эмпирического исследования феномена этноцентризма, которые были получены с использованием методик анкетного опроса касательно восприятия разных культурных образцов и ранжирования степени их схожести и привлекательности для респондента. Применена концепция культуральности, которая позволяет построить модель происхождения и функционирование этноцентризма и объяснение причин негативизма, что им порождается. Впервые классифицированы и описаны качественные признаки трех принципиально разных типов этноцентризма: естественного, защитного и самоценного. Определено, что этноцентризм есть частью бытия личности, следствием ее социализации и причастности к конкретной культуре. Установлено, что этноцентризм является не только препятствием в межэтническом и межкультурном взаимодействии, но выполняет функцию поддержания и сохранения этнической идентичности личности, целостного представления о внутреннем и внешнем мире.

Ключевые слова: этноцентризм, межкультурная коммуникация, глобализация, культура, культурная личность.

Вступ. Сучасний світ інтенсивно глобалізується. Темпи інтегративних процесів між країнами, економічними системами, ідеологічними доктринами постійно зростають. Існують суттєві об’єктивні причини цієї динаміки, основна 
3 яких полягає у можливості виключно колективних форм безпеки людства, якщо розуміти ії як певну цілісність.

Однак, повна світоглядна картина сучасності обов'язково повинна включати і зворотній процес - активної диференціації людських спільнот визначеного і спрямованого культурного сепаратизму. Більшість науковців у галузях, що традиційно вважаються гуманітарними (тобто - людинознавчими) сходяться у розумінні полікультурності сучасного соціального середовища. Причому ознаки полікультурності констатуються на всіх рівнях соціальної інституалізації, адже будь-яка держава і більшість ії соціальних інститутів існують в полікультурному просторі. Існують політичні, економічні, національні чинники, які зумовлюють наявність державних кордонів. Вони розмежовують культурні процеси, надаючи їм певної специфіки. Але $є$ і більш глобальні межі: «географічна» - між Сходом і Заходом; релігійна - між християнським i мусульманським світом; навіть «арифметична» - говорять про «велику сімку», «країни третього світу» і т. д.

Культура розкриває свій зміст через систему норм, цінностей, значень, ідей і знань, що отримають вираження в системі моралі і права, у художній сфері i науці. Разом 3 тим про культуру суспільства, іiі характеристики, принципи і динаміку з психологічної точки зору варто розглядати не тільки за власне «культурними» проявами: художня продукція, релігія, право, наука і т. д. Культура існує також у практично-дійовій формі, у формі подій і процесів, у яких проявилися установки й орієнтації учасників, тобто різних соціальних груп і індивідів.

Метою статті $\epsilon$ аналіз змісту установок особистості, що формуються у власній культурі та їх впливу на сприйняття зразків ін. етноспецифічних культур.

Аналіз основних досліджень і публікацій. У сучасних дослідженнях міжкультурної комунікації в основному зберігаються західні наукові традиції у підходах до цього складного і суперечливого явища $[16 ; 17 ; 18]$.

Аналізу міжкультурної комунікації присвячені праці С. Авєрінцева, М. Мамардашвілі, Ю. Лотмана, Б. Успенського, Ф. Лосєва [7]. У цих рамках можливо розглядати культурні феномени як знаки, які несуть у собі значення, інформацію, i вийти на побудову інформаційних моделей культурних процесів [13].

Глобалізація, вимушена i невимушена міжкультурна комунікація породжують нову проблему - проблему адаптації, що фактично є процесом пристосування особистості до умов конкретного культурного середовища, тобто ціннісним вибором, що визначає ключові характеристики культурного буття: обов'язкове внутрішнє прагнення особистості до удосконалення; активну взаємодію людини 3 культурним середовищем. Завжди важливий результат 


\section{СТАТУС ЕТНОЦЕНТРИЗМУ В МІЖКУЛЬТУРНІЙ ВЗАЕМОДІї, ЙОГО ВИДИ ТА ФУНКЦІї}

взаємодії у системі «людина - культурне середовище»; мета, до якої прагне особистість [1;4].

На першому етапі дослідження у руслі міжкультурної комунікації орієнтувалися на проблеми міжкультурних відмінностей, аналіз взаємовідносин між ними i характерною поведінкою носіїв культур [8]. Основою для міжкультурних досліджень післявоєнного часу стають проблеми культури і особистості, поява т. зв. «культурної моделі». Дослідження, що займаються проблематикою міжкультурних відмінностей, свідчать про три підходи до аналізу міжкультурної комунікації: 1) перший підхід базується на класичній позитивістській методології суб'єктно-об'єктних відносин, що представлений концепцією структурного функціоналізму, системним методом та концепцією інформаційного суспільства (Д. Белл, А. Тоффлер); 2) другий підхід базується на методологічному підході (Ю. Габермас), що базується на когнітивній моделі суб'єкт-об'єктних відносин, в якій сфера комунікації виділяється в якості особливого онтологічного об’єкта. Ї̈̈ вивчення базується на методах герменевтичної інтерпретації смислів, критичній рефлексії, раціональній реконструкції; 3) третій (постнекласичний) підхід зводить природу соціального до суб'єктивно-об' єктивним відносинам, тобто до принципу інтерсуб'єктивності i виключає об'єктність. Суспільство розглядається як мережа комунікацій, комунікації створюють можливість для самоопису суспільства та його самовідтворення (Н. Луман) i виступають як активне самоорганізоване середовище [12].

Міжкультурна комунікація - це наукова етика, яка намагається розробити наукові методи для покращення взаєморозуміння і міжкультурного обміну. Однією 3 причин виявлення інтересу до міжкультурної комунікації $\epsilon$ розвиток людської цивілізації, інтернаціоналізація і глобалізація. Міжкультурна комунікація - це комунікація між представниками різних культур і народів, і здійснюється вона тільки тоді, коли між людьми різних культур розвивається «міжкультурна компетентність» [10]. Сучасні геополітичні зміни випробують збалансованість між нацією, територією і державою, збалансованість, яка визнається і забезпечується, головним чином, національними системами [11].

У культурі знаходить вираження багатство i різноманітність громадського життя, а разом із тим його системність, що підтримує єдність суспільства i наступність його розвитку. Через соціальні i професійні субкультури відбувається адаптація людини до потреб складної діяльності [2].

Своєрідність міжкультурної комунікації досліджують різні галузі знання: соціологія, культурологія, культурна антропологія, лінгвокраїнознавство, етнолінгвістика, етнопсихологія тощо. Але аналіз міжкультурної комунікації саме $з$ точки зору соціальної філософії дозволяє здійснити осмислення буття 


\section{СТАТУС ЕТНОЦЕНТРИЗМУ В МІЖКУЛЬТУРНІЙ ВЗАЕМОДІї, ЙОГО ВИДИ ТА ФУНКЦІї}

людини і суспільства через конкретні культурні форми, соціальні умови та механізми, що зберігають національну і культурну ідентичність [3].

У контексті міжкультурної комунікації також розглядаються проблеми глобалізації культури та взаємодії цивілізацій, обговорення яких відбувається на науково-теоретичних конференціях і круглих столах. Варто також зауважити, що міжкультурна комунікація як навчальна дисципліна вже викладається в багатьох університетах США, країн Європи та в Росії [7].

В Україні предметне поле досліджень у рамках проблематики «міжкультурна комунікація» тільки формується. Цю проблему розробляють у різнопланових працях $\quad$ В. Андрущенко, Н. Висоцька, О. Гриценко, Л. Губерський, . Дзюба, П. Донець, В. Свтух, А. Єрмоленко, Г. Касьянов, М. Кушнарьова, Л. Нагорна, А. Приятельчук, М. Обушний, П. Скрипка [5].

Важлива сторона культурного життя - плюралізм культур, що розкривається через аналіз проблематики самобутності і взаємодії культур на етнічному, національному і цивілізаційному рівнях. Ці рівні складаються в ході адаптації спільноти до умов середовища (географічних, кліматичних, ландшафтних, ресурсних тощо), формату внутрішнього спілкування, що історично складається в групі, і взаємодії між сусідніми соціумами.

Великою перешкодою міжкультурній взаємодії є етноцентризм. Так, більшість людей судять про чужі культурні цінності, використовуючи як стандарт власні. Цей тип ціннісного судження і називають етноцентризмом. Етноцентризм I. Кон визначає як «схильність розглядати явища та факти чужої культури, чужого народу через призму культурних традицій та цінностей свого власного народу» [6].

Психологічна основа такого явища міститься в особливостях механізму сприйняття, на яке завжди, більшою або меншою мірою, впливає особистий досвід індивіда. В етноцентризмі завжди більшою мірою присутній емоціональний компонент. I, нарешті, етноцентризм, хоча і пов'язаний 3 порівнянням особливостей будь-якої нації з особливостями своєї, необов язково передбачає некритичне ставлення до способу життя і особливостей останньої. Разом із тим, етноцентричні комунікатори не усвідомлюють, що люди розвивають свою культуру для того, щоб зробити осмисленим власне життя і встановити порядок у своїх суспільствах.

Існує чотири типи властивостей людей, що ускладнюють міжкультурну взаємодію, роблять їі неможливою або малопривабливою для учасників.

Інертність мислення. Ця властивість свідомості не є ні позитивною, ні негативною, якщо розглядати їі поза конкретною ситуацією взаємодії людей, чи груп людей. Але в реальному житті вчинки людей оцінюються за тим, як вони співвідносяться з вимогами ситуації. 


\section{СТАТУС ЕТНОЦЕНТРИЗМУ В МІЖКУЛЬТУРНІЙ ВЗАЕМОДІї, ЙОГО ВИДИ ТА ФУНКЦІї}

У психологічному сенсі інертність - це опір змінам переконань, поглядів, що спирається на здібність людини протягом довгого часу утримувати в пам'яті інформацію, корисність якої багаторазово підтверджується практичною діяльністю. Наприклад, стійкість у боротьбі за свої переконання теж грунтується на інертності мислення. Така інетність, як відомо, оцінюється позитивно, якщо переконання, що зберігаються завдяки їй, співзвучні потребам суспільства. Але якщо розвиток суспільства створює нову соціально-культурну ситуацію, в якій попередні погляди і переконання вже не відображають дійсного стану речей, то тоді інертність чинить опір пеобхідності перебудови мислення людини, його психолоогії, отже, є негативним фактором.

Догматизм - теж одна із серйозних перешкод психологічної перебудови міжкультурної взаємодії. По відношенню до особистості він означає неспроможність критично оцінювати істини, що вже засвоєні. Догматизм в психологічному відношенні спирається на інертність мислення, але свою назву він отримав не від цієї властивості, а від ідеї (правила, принципу), що утримується свідомістю (і підсвідомістю) безвідносно до умов життя.

Консерватизм, який близький до догматизму. Але якщо догматика примушує дотримуватися догми головним чином сліпою прихильністю до неї, втрата здібності оцінювати іï критично, то консерватор понад усе боїться нововведень, він обділений почуттям новго, виступає не стільки на захист догми, скільки проти новацій. Для консерватора важливий статус-кво, навіть якщо йому не досить затишно при ньому; але зовсім не припустимий новий стан, навіть якщо він обіцяе серйозне покращення. Неясність майбутнього, пов'язаного 3 новацією, його невизначеність можуть лякати консерватоора більше, ніж «погане» теперішнє.

Охоронне мислення - різновид консерватизму і догматизму водночас, і воно носить особливо активний, агресивний характер. Людина, що відрізняється охоронним мисленням, приписує собі придуману нею самою ж функцію захисту різноманітних догм від усіх інакодумців [9].

Етноцентризм як характеристика образу своєї чи чужої групи виникає у процесі спілкування етносів на основі двох діалектично пов'язаних процесів: зближення i відокремлення. Взаємодія етнічних груп супроводжується адаптаційними процесами, які можуть протікати в різних формах: від міжетнічних інтеграцій до етнокультурної ізоляції. Успішна адаптація етнічних груп у вигляді інтеграції пов'язана із позитивним відношенням як до культури власної, так і до культури етнічних груп, що знаходять вираження у формуванні позитивно направлених авто- та гетеростереотипів.

Дезадаптація етнічних груп, крайній полюс якої представляє етнокультурна ізоляція, передбачає надтолерантність до власної культури при 
повній відмові від культури етноконтактних груп, що виражається в наявності надпозитивних автостереотипів і негативних гетеростереотипів.

Таким чином, термін «етноцентризм» у його широкому розумінні використовується для позначення специфічного феномена щоденної свідомості, що виникає у процесі взаємодії етнічних груп і який характеризується надпозитивним відношенням до інгрупи i негативним емоційно-оцінним відношенням до аутгрупи.

Виклад основного матеріалу. Аналіз феномену етноцентризму показує, що існує кілька важливих проблем. По-перше, негативне забарвлення етноцентричних суджень. Чи можливо їх уникнути? По-друге, фактори, що породжують етноцентризм. Чи можна впливати на них? Найбільш загальним питанням очевидно є таке: чи можливо подолати етноцентризм і яким чином?

Ми пропонуємо структурну модель феномену етноцентризму, яка поєднує різні підходи і дозволяє дати відповідь на ці запитання.

Із нашої точки зору, етноцентризм $є$ особистісною установкою, яка формується у процесі соціалізації індивіда в певній культурі. Це формування починається 3 самих ранніх етапів онтогенезу. Стадії формування етноцентризму пов'язані з формуванням свідомості та самосвідомості в цілому. Спочатку формуються сенсорні еталони, які є культурно специфічними, а отже, і еноспецифічними. Далі формуються моральні, поведінкові норми та ієрархічна система ціннісних орієнтацій, які теж строго культурно визначені. Усі ці засвоєні еталони (сенсорні, нормативні, ціннісні) служать для сприйняття та оцінювання людиною себе та ін. людей. Функціонуючи у спілкуванні вони $\epsilon$ основою для порівняння і завжди виявляють схожість або несхожість позицій. У результаті такого порівняння виникає емоційна оцінка: позитивна у випадку схожості і негативна у випадку несхожості. Вираженість емоційного супроводу залежить і від міри схожості-несхожості, і від характеристик еталону, що був задіяний.

Основний закон етноцентризму полягає в тому, що чим більш виразною $\epsilon$ несхожість за всіма критеріями, тим яскравішим буде негативізм.

Модель етноцентризму, що пропонується, має три основні компоненти: стандарти - порівняння - емоиії.

Описаний механізм походження етноцентричних суджень перевірявся в експериментальному дослідженні, в якому брало участь 180 піддослідних різного віку, які ідентифікували себе як українці. Усім їм пропонувалося оцінити своє ставлення до певного набору предметів ін. етнічної культури. Стимульний матеріал поділявся на вербальний і невербальний.

Вербально було пред'явлено зразки фольклору - прислів'я, короткі притчі-казки, та описи ритуалів, прийнятих у чужій етнічній групі. Невербальним матеріалом виступали зображення елементів декоративно- 
ужиткового мистецтва. Усі стимульні зразки були класифіковані експертами за 5-ти бальною шкалою за ступенем несхожості 3 відповідним культурним матеріалом, що функціонує в рідній для піддослідних етнічній групі. Таким чином, було виділено три групи предметів: а) дуже схожі; б) такі, що незначно відрізняються; в) дуже відмінні.

У результаті експерименту було встановлено:

- кількість оцінок предметів як таких, що «не подобаються» прямо пропорційно залежить від ступені їх несхожості на притаманні власній культурі. Так, у першій групі (а) таких оцінок було $11 \%$, у другій (б) - вже $31 \%$, а в третій - аж $74 \%$.

- респонденти більш старшого віку частіше демонструють етноцентризм (у віці 12-15 р. він виражається у 20-25\% суджень, у людей старших 40 р. у $55-65 \%)$.

- найвищий рівень етноцентризму виявляється в реакції на стимульний матеріал, що містить опис традиційних обрядів та ритуалів чужої культури. Саме вони викликають спектр негативних емоцій (від подиву до відрази).

Концепція культуральності [13] дозволяє побудувати модель походження та функціонування етноцентризму та пояснити причини негативізму, що ним породжується.

Інструментальна інваріанта культуральності містить малоусвідомлені сенсорні кліше та перцептивні еталони, які, фактично, є засобами сприйняття предметів оточуючого світу (незалежно від аналізатора). Зрозуміло, що вони культурно-адаптовані і можуть давати збій при створенні адекватного образу предметів ін. культури. Це явище доступне кожному навіть у самоспостереженні - так, звуки незрозумілої та фонетично побудованої та ін. артикуляції мови здаються «різкими», «гавкітливими» чи писклявими. Це ж стосуються i кольористики, і оцінки смаку справ національної кухні.

Ціннісно-нормативна інваріанта задає еталони поведінки, однак вони більш усвідомлені, конвенціональні і недирективні.

Найбільш універсальною i загальноцивілізаційною $\epsilon$ інваріанта самовизначення. У структурі етнічності це зона, що найбільш вільна від специфіки вузькогрупових та етнічних настанов і є загальнокультурною (в тому сенсі, що і поняття «культура» визначається як загальнолюдське).

У полі самореалізації порівняння, що виявляє несхожість осмислюється людиною не як негативний факт, а як очевидний, обов'язковий і схвальний. Лише в окремих (і як засвідчують чисельні дослідження, штучно створених умовах) самовизначення людини та іiі етнічної групи може будуватися на запереченні права на вільний культурний розвиток, на самоствердження за рахунок приниження ін. Це явище називають у літературі «гіперетнічність». У термінах концепції культуральності, зрозуміло, що гіперетнічність означає 
поширення етнічних настанов на сферу, де етнічна специфіка $є$ необхідною умовою, але не рушійною силою розвитку людини, де існує діалектичне заперечення фіксованої заданості. У публіцистичних поняттях гіперетнічністю можуть називати націоналізм, шовінізм чи національна нетерпимість.

Таким чином, концепція культуральності дозволяє розглядати три типи етноцентризму, який визначається як негативізм (виникнення певного типу негативної емоційної реакції) у взаємодії 3 несхожими (своєрідними, специфічними, самобутніми) культурними явищами і проявами [14].

Перший тип зумовлений відсутністю потрібних сенсорних (а значить i естетичних) ключів розпізнавання чужих культурних явищ, що формуються як інструментальна інваріанта культуральності. Це інструментальний етноцентризм. Якщо розуміти психологічну природу формування пізнавальної сфери людини, його можна вважати «природним», натуральним.

Другий тип етноцентризму виникає внаслідок розходження в цінніснонормативних стандартів, а значить очікувань, імпліцитних теорій соціальних явищ та способів їх розпізнавання пояснення. Якщо в першому типі несхоже оцінюється як некрасиве, а отже і неприємне, то в цьому випадку несхоже скоріш за все розцінюється як загрозливе і небезпечне, звідси і виникає емоція із спектру негативних.

Цей тип етноцентризму можна назвати захисним. Прояви етноцентризму цього типу можуть бути дуже різноманітними. Очевидно $є$ сенс співвіднести їх 3 відомими класифікаціями захисних психологічних механізмів. Майже всі відомі концепції етноцентризму та його експериментальні дослідження апелюють до етноцентричних реакцій другого типу.

Tретій тип етноцентризму не $\epsilon$ ні природним, ні захисним. Він виникає в певній «неспецифічній» зоні як штучний феномен. Оскільки він конструюється в сфері інваріанти самовизначення i регулюється екзистенціальними механізмами, його можна назвати самоцінним. Саме з таких причин, що цей тип етноцентризму є штучним, але виникає на основі процесу реалізації глибинних смислових аспектів життєдіяльності, він i $€$ найбільш войовничим та небезпечним.

Зафіксуємо все викладене вище (рис. 1). 

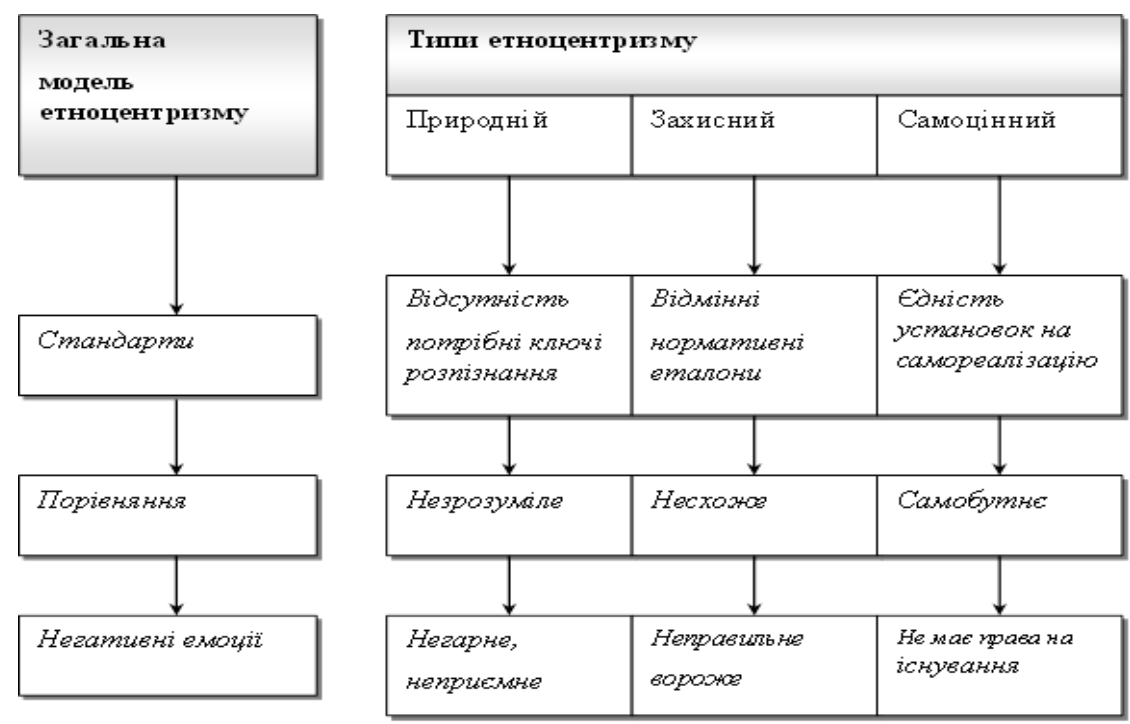

\section{Рис 1. Типи етноцентризму}

Можна розглянути етноцентризм з точки зору рівневої організації, що закладалася в концепцію культуральності на рівні інтенції праксису та рефлексії. Зрозуміло, що треба визнати інтенціонально можливими всі типи та форми етноцентризму. Оскільки етноцентричні реакції супроводжуються негативними емоціями, то на рівні праксису домінує тенденція до уникнення, дистанціювання від відповідних ситуацій. Лише 3 рівня рефлексії можливе регулювання та подолання етноцентризму. Саме у формуванні рефлексивної позиції більшість дослідників бачать шляхи виникнення толерантності як альтернативи руйнівним для взаємодії властивостям етноцентризму.

Висновки. Етноцентризм, як інші соціально-психологічні явища, не варто розглядати як щось позитивне чи негативне, оскільки ціннісне судження про нього не може бути прийнятним. Так, етноцентризм є частиною буття особистості, наслідком іï соціалізації та прилучення до конкретної культури. Незважаючи на те, що етноцентризм часто буває перешкодою у міжетнічній та міжкультурній взаємодії, він виконує функцію підтримання та збереження етнічної самоідентичності, цілісності та специфічності.

\section{Список використаних джерел:}

1. Асмолов А. Г. Психология личности: принципы общепсихологического анализа / А. Г. Асмолов - Москва: Смысл: Академия, 2002. $-416 \mathrm{c}$.

2. Бернс Р. Развитие Я-концепции и воспитание / Р. Бернс. - Москва: Прогресс, 1986. - 169 с 
3. Бромлей Ю. В. Очерки теории этноса / Ю. В. Бромлей. - Москва: Наука, 1984. - 418 с.

4. Грушевицкая Т. Г. Основы межкультурной коммуникации: учеб. для вузов / Т. Г. Грушевицкая, В. Д. Попков, А. П. Садохин. - Москва: ЮНИТИДАНА, 2003. $-352 \mathrm{c}$.

5. Європейські студії / упоряд., передм. Т. А. Устименко. - Полтава: ACMI, 2011. - $156 \mathrm{c}$.

6. Кон И. С. В поисках себя: Личность и ее самосознание / И. С. Кон. Москва: Политиздат, 1984. - 335 с.

7. Пашукова Т. И. Этноцентризм в межкультурной коммуникации [Электронный pecypc] / Т. И. Пашукова // Вестник Московского государственного лингвистического университета. - 2009. - URL: http://cyberleninka.ru/article/n/etnotsentrizm-v-mezhkulturnoy-kommunikatsii. Загл. с экрана. - Дата обращения: 28.02.2017.

8. Поршнев Б. Ф. Социальная психология и история / Б. Ф. Поршнев. Москва: Наука, 1966. - 211 с.

9. Рыжова С. В. Психологическая составляющая этнонационализма / С. В. Рыжова // Этническая психология и общество: материалы I конф. секции этнической психологии при РАО / отв. ред. Н. М. Лебедева. - Москва: Старый сад, 1997. - С. 173-181.

10. Сатарова Л. Х. Основные проблемы межкультурной коммуникации как фактор развития современного общества [Электронный ресурс] / Л. Х. Сатарова // Современ. науч. исслед. и инновации. - 2013. - № 12. - URL: http://web.snauka.ru/issues/2013/12/29074. - Загл. с экрана. - Дата обращения: 14.03.2017.

11. Солдатова Г. У. Межэтническое общение: когнитивная структура этнического самосознания / Г. У. Солдатова // Познание и общение. - Москва: Наука, 1988. - С. 111-125.

12. Соснин В. А. Культура и межгрупповые процессы: этноцентризм, конфликты и тенденции национальной идентификации / В.А. Соснин // Психолог. журн. - 1997. - № 1. - С. 50-60.

13. Тер-Минасова С. Г. Роль языка в формировании личности. Язык и национальный характер / С. Г. Тер-Минасова // Этносоциолингвистика: хрестоматия / [авт.-сост. Н. И. Коновалова]. - Екатеринбург: Урал. гос. пед. унт, 2004. - C. 241-249.

14. Устименко Т. А. Основи міжкультурної взаємодії / Т. А. Устименко. - Полтава: Техсервіс, 1998. - 214 с.

15. Устименко Т. Розвиток особистості i функції культури / Т. Устименко // Особистість в освіті: парадигма культури: монографія / В. В. Зелюк, В. Ф. Моргун, Т. А. Устименко. - Полтава: АСМІ, 2011. - 212 с.: іл. 
16. Шихирев П. Н. Современная социальная психология в Западной Европе. Проблемы методологии и теории. / П. Н. Шихирев. - Москва: Наука, 1985. $-175 \mathrm{c}$.

17. Bart R. Ethnic groups and boundaries [Electronic recource]: The social organization of culture difference / R. Bart. - Oslo, 1969. - Mode of access: http://isites.harvard.edu/fs/docs/icb.topic446176.files/Week_4/Barth_Introduction_Eth nic_Groups_and_Boundaries_.pdf. - Last access: 27.02.2017. - Title from the screen.

18. Sumner W. The Science of Society / W. Sumner, A. Keller. - New Haven: Yale University Press, 1942.

\section{References:}

1. Asmolov, A.G. (2002). Psychology of personality: principles of general psychological analysis. Moscow: «Smysl», Publishing Centre «Akademija».

2. Berns, R. (1986). Development of self-concept and education. Moscow: Progress.

3. Bromlej, Ju.V. (1984). Essays on the theory of ethnos. Moscow: Nauka.

4. Grushevickaja, T.G. (2003). Basics of Intercultural Communication: A Textbook for Universities. Moscow: JuNITI-DANA.

5. European studios. (2011). Poltava: «ASMI» LTD.

6. Kon, I.S. (1984). In search of yourself: Personality and self-awareness. Moscow: Politizdat.

7. Pashukova, T.I. (2009). Ethnocentrism in intercultural communication. Vestnik Moskovskogo gosudarstvennogo lingvisticheskogo universiteta [Bulletin of Moscow State Linguistic University] [online] Available at: http://cyberleninka.ru/article/n/etnotsentrizm-v-mezhkulturnoy-kommunikatsii. [Accessed 28 February 2017]. Title from the sreen.

8. Porshnev, B.F. (1966). Social psychology and history. Moscow: Nauka.

9. Ryzhova, S.V. (1997). The psychological component of ethno-nationalism. Ethnic psychology and society: materials of the 1st conference of the section of ethnic psychology at RAO, Moscow: «Staryj sad», pp. 173-181.

10. Satarova, L.H. (2013). The main problems of intercultural communication as a factor in the development of modern society. Sovremennye nauchnye issledovanija $i$ innovacii [Modern scientific research and innovations], no. 12, [online] Available at: http://web.snauka.ru/issues/2013/12/29074. [Accessed 14 March 2017]. Title from the sreen.

11. Soldatova, G.U. (1988). Interethnic communication: the cognitive structure of ethnic self-awareness. Cognition and communication. Moscow: Nauka, pp. 111-125. 
12. Sosnin, V.A. (1997). Culture and intergroup processes: ethnocentrism, conflicts and tendencies of national identity. Psihologicheskij zhurnal [Psychological journal], no. 1, pp.50-60.

13. Ter-Minasova, S.G. (2004). The role of language in the formation of personality. Language and national character. V: N.I. Konovalova. Jetnosociolingvistika: hrestomatija [Etnosotsiolingvistika: anthology]. Ekaterinburg: Ural State Pedagogical University, pp. 241-249.

14. Ustymenko, T.A. (1998). Fundamentals of intercultural interaction. Poltava: Tekhservis.

15. Ustymenko, T. (2011). The development of personality and the function of culture. V: V.V. Zeliuk, V. F. Morhun, T. A. Ustymenko. Osobystist $v$ osviti: paradyhma kultury: monohrafiia [Personality in education: paradigm of culture: monography]. Poltava: «ASMI» LTD.

16. Shihirev, P.N. (1985). Contemporary Social Psychology in Western Europe. Problems of methodology and theory. Moscow: Nauka.

17. Bart, R. (1969). Ethnic groups and boundaries: The social organization of culture difference [online] Available at: http://isites.harvard.edu/fs/docs/icb.topic446176.files/Week_4/Barth_Introduction_Eth nic_Groups_and_Boundaries_.pdf. [Accessed 27 February 2017]. Title from the screen.

Press.

18. Sumner, W. (1942). The Science of Society. New Haven: Yale University

(C) Устименко Т. А., 2018 